\title{
Post Tsunami Heavy Mineral Distribution Between Cuddalore to Kanyakumari Along the Tamil Nadu Coast, India - A Review
}

\author{
M. Suresh Gandhi ${ }^{1}$ et al. ${ }^{*}$ \\ ${ }^{1}$ Department of Geology, University of Madras, Chennai
}

India

\section{Introduction}

Placer deposits are formed as a result of the selective concentration of valuable minerals from the disintegration and redeposit ion of the rock fragments. Beach sands contain the most economically important minerals accumulations; wave action deposits sand on the beach and the heavy minerals are concentrated when backwash carries some of the lighter minerals such as quartz back into the sea.

Onshore winds which preferentially blow lighter grains inland can lead to higher concentrations of heavy minerals at the front of coastal dunes. Old 'fossil' shorelines known as strandlines can now be found some distance inland.

Minerals with following inherent characteristics can be accumulated as placers such as high specific gravity and, chemical strength to resist the denudating action of transporting agent. Placer deposits can be broadly classified on the basis of mode of origin and transportation into eluvial, deluvial, proluvial, alluvial (sub divided into bar, channel fill, valley delta and bench or terrace placers) lateral (subdivided into lacustrine, beach, marine beach, and offshore placers) glacial (subdivided into marine and fluvioglacial) and Aeolian placers (Smirnov, 1976). Rajamanickam (1993) has classified (l) marine placers including raised beaches (2) offshore placers including (i) ongoing and (ii) palaeo/fossil placers of both buried and exposed types. Many works are concentrated on beach placers (Angusamy and Rajamanikcam, 2000, Cherien, 2003, Mohan, 2001) however, only limited work has been carried out for tsunami placer mineral studies. Worldwide tsunami impacts of the last century have been documented by many researchers (Heck, 1947; Iida et al., 1967; Nakata et al, 1993; Lander and Whiteside, 1997; NGDC, 2001 and Shi et al 1995, Maramai et.al., 2005; McMurtry et. al., 2004; Scheffers and Kelletat, 2003; Tappin et.al., 2001; Nanayama et. al., 2000; Clague et.al., 2000; Dominey-Howes et. al., 2000; Papadopoulos and Chalkis 1984; Monge and Mendoza, 1993; Mörner, 1999). (Angusamy \& Rajamanickam 2000) have studied

\footnotetext{
* A. Solai ${ }^{1}$, Sivaraj Kaveri², Kasilingam Kanan ${ }^{1}$, Venkatesan Dhamodharan"1, Kuppusamy Baskar ${ }^{3}$ and Victor Rajamanickam ${ }^{4}$

${ }^{1}$ Department of Geology, University of Madras, Tamil Nadu, India

${ }^{2}$ Department of Geology, Anna University, Tamil Nadu, India

${ }^{3}$ Department of Applied Geology, University of Madras, Tamil Nadu, India

${ }^{4}$ Research Director, Sairam Engineering College, Tamil Nadu, India
} 
the distribution of heavy minerals between Kanyakuami and Mandapam. World reserves of ilmenite are estimated at 460 MT. The total world production of ilmenite in 2001 was 6523 thousand tones. Of this Canada ranks first, consisting 29\% followed by Australia (25\%). south Africa (23\%) while India accounted for 5\% (www.tzmi.com). India is rich in placer mineral deposits, but three is an uncertainty about the extent of mineral resources due to the non availability of inventory of resources. India's coastline of $6800 \mathrm{~km}$ is hosted by placer deposits of various grades and size. Indian resources constitute about $35 \%$ of world resources of ilmenite, $10 \%$ of rutile, $14 \%$ of zircon and $71.4 \%$ of monazite (Rajamanickam, et al., 2005). Loveson et al., (2008) observed the inferences from sudden changes in the sedimentological processes during the December 26, 2004 tsunami along the east coast of India. In India the detailed investigations have been done around $28 \%$ of the beaches and still many parts of inlands and offshore regions along east and west coasts of India remain unexplored.

Hence, an attempt has been made on detailed exploratory studies from post tsunami sediments along the Tamil Nadu coast by an integrated approach. This paper is mainly focused on record of heavy minerals during the post tsunami events.

\section{Heavy mineral}

Heavy Minerals having a density greater than $2.9 \mathrm{~g} / \mathrm{cm} 3$. The term is most commonly used to denote high-density components of siliciclastic sediments. Most heavy mineral studies are undertaken to determine sediment provenance, because heavy mineral suites provide important information on the mineralogical composition of source areas. Since heavy minerals rarely constitute more than $1 \%$ of sandstones, their study normally requires them to be concentrated.

Heavy minerals have important economic applications. Their use in paleogeographic reconstructions, especially in elucidating sediment transport pathways, is of particular value in hydrocarbon exploration, and their use in correlation has important applications in hydrocarbon reservoir evaluation and production. Recent advances have made it possible to utilize the technique on a real-time basis at the well site, where it is used to help steer high-angle wells within the most productive reservoir horizons. Heavy minerals may become concentrated naturally by hydrodynamic sorting, usually in shallow marine or fluvial depositional settings. Naturally occurring concentrates of economically valuable minerals are known as placers, and such deposits have considerable commercial significance. Cassiterite, gold, diamonds, chromite, monazite, and rutile are among the minerals that are widely exploited from placer deposits. See also Dating methods; Monazite; Placer mining; Well; Zircon.

Heavy minerals have important economic applications. Their use in paleogeographic reconstructions, especially in elucidating sediment transport pathways, is of particular value in hydrocarbon exploration, and their use in correlation has important applications in hydrocarbon reservoir evaluation and production. Recent advances have made it possible to utilize the technique on a real-time basis at the well site, where it is used to help steer highangle wells within the most productive reservoir horizons. Heavy minerals may become concentrated naturally by hydrodynamic sorting, usually in shallow marine or fluvial depositional settings. Naturally occurring concentrates of economically valuable minerals are known as placers, and such deposits have considerable commercial significance. Cassiterite, gold, diamonds, chromite, monazite, and rutile are among the minerals that are widely exploited from placer deposits. Recently heavy mineral studies widely used in distinguish the tsunamisediment deposits from modern beach sediments. 


\section{Study area}

The present study area extends from Cuddalore in the north to Kanyakuamri in the south of Tamil Nadu. The drainage pattern of the study area is control mainly by the perennial river like Gadilam, Pallar, Cavary, Tamiraparani. The beaches in the study region are composed of rocky/sandy material. Coralline rocks are exposed in the coastal segment of the Tuticorin - Alantalai region. At a few places, the calcareous sandstone shows a clear stratification with a seaward dip of less than $10^{\circ}$.

\section{Methodology}

A systematic coastal survey done from 2005 to till-date by seasonal sample collection. In the coastal stretch from Cuddalore to Knanyakuamri, more than 150 sediment samples have been collected using a hand auger at an interval of 5 to $10 \mathrm{~km}$ between the sampling stations. Using a hand held Magellan GPS, geographical co-ordinates were fixed for the sample locations. Beach samples were washed and dried. After coning and quartering, carbonates, organic matter and ferruginous coatings were removed from the samples by treatment with $1: 10 \mathrm{HCl}$, $30 \%$ by volume $\mathrm{H}_{2} \mathrm{O}_{2}$ and $\mathrm{SnCl}_{2}$, respectively. The dry samples were sieved at Ro-Tap sieve shaker for 15 minutes. Heavy mineral separation was carried out by using bromoform of 2.89 specific gravity following the procedure of Milner (1962). Separated heavies were washed and then mounted on the glass slide using the Canada balsam.

\section{Results}

\subsection{Cuddalore and Pondicherry (M.Suresh Gandhi \& A.Solai,2010)}

The heavy minerals are dominant in Cuddalore (26.43\%) and Kannikovil (28.48\%) regions in the surface samples when compare to other regions. The percent of enrichment in other zones are Kottaikupppam(8.14 \%), Veeranampattinam (12.18 \%) and Pudukuppam (12.83 $\%)$. In Cuddalore the heavy mineral weight \% shows that at the depth of $0-25 \mathrm{~cm}$ the percentage is gradually increasing and from the depth of $40 \mathrm{~cm}$ to $80 \mathrm{~cm}$ a sudden decreasing trend is noticed. Zircon and Garnet is found in the high percentages at Pondicherry - Cuddalore region. Kyanite is dominated in the Pondicherry (Kottaikuppam) region whereas in the other zone it is generally lesser. Chlorite is dominant in all the zones. The non opaque distribution in the sector the different grain sizes within the sector has established the prevalent presence of chlorite, kyanite, garnet, zircon and epidote.

\subsection{Nagapattinam (D.Soosai, R. Chandrasekaran, A.R.Gujar, V.J.Loveson, N. Angusamy, N Chandrasekar and G.V.Rajamanickam)}

In the present study, it is evident, that though all the stations are located in N-S trending coastal configuration, annual profile has hardly brought in any drastic variations in the beach profiles. It has resulted in substantial addition or erosion of the sediments. It has also brought out that beaches in the study area were under equilibrium conditions before tsunami. But however, after tsunami, a total change in the beach morphology is observed. Even though all the stations are located in N-S trending coastline, tsunami has brought in deposition of sediments in Nagoor and Chinnankudi. This has brought out the influence of shelf bathymetry in the redistribution of tsunami effects along the beaches. The present study highlights that destruction left by tsunami is enormous in the beaches of Poompuhar 
and Karaikkal and it calls for undertaking beach nourishment techniques to restore the beach to its original condition. After the tsunami, the modality is shifted to a slight coarser grade in all the beaches in such a way an enrichment of concentration is noticed in 50 mesh size grade also. In the Total heavy mineral by wt \%, shows that post-tsunami samples Chinnankudi an upshoot of heavies to a tune of $93 \%$ in the Berm of Nagoor and HT of Chinnankudi. At Poompuhar, the distributions of heavy minerals are found to be different to other two stations. While Poompuhar establishes overall rise in the Wt \% of heavy minerals during Post Tsunami like other stations, from Dec.2003 to Dec. 2004 unlike other stations, it is not giving any higher percentage in LT and Berm samples. Chinnankudi maintains always a higher percentage in LT, HT and Berm too, except post tsunami conditions when compared to Nagoor. When the distribution of heavy minerals in LT, HT and Berm is considered station wise during the years 2003, 2004 and 2005. Poompuhar is seemed to behave different to others. The heavy mineral enrichment increases from North (Poompuhar) to the South (Nagoor) in the study area. The same may be attributed to the inner shelf gradient.

\subsection{Mandapam to Vedaranyam (G.V.Rajamanickam, 2005)}

Placer mineral are formed as a result of disintegration of heavy minerals as suitable places. The heavy minerals serve as an index for stratigraphic correlation of unfossilferrous strata. The study area extends from Thondi to Manamelkudi in the Palk Strait, Southeast coast of India.

The highest percentage of heavy minerals shown at R.Pudhupattinam (38.64 \%), is ascribed it accurate coast line and lowest percentage of heavy minerals recorded at Thondi $0.86 \%$. The landforms help to infer the various stages of sea level regression and transgression takes place in the study region.

\subsection{Tamiraparani Estuary and Off Tuticorin (A. Solai, M. Suresh Gandhi, K. Chandrasekaran and V. Ram Mohan, 2009)}

90 sediment samples were collected during Feb 2005, at Tamirabarani river, estuary and offshore using Vanveen grab sampler. An alternate higher and lower percentage is noticed in the river samples may be due to the nature of the river course. Over all the higher percentage is noticed in the river and estuary samples (34.8\%) may be due to due to the fast moving action of wind and water. In few places in the estuary the heavy mineral distribution are lesser in amount $(0.8 \%$ to $11.6 \%)$. Due to the movement of sediments from river and the erosional activities, the deposition of heavy mineral is not feasible the station near Estuary and rivermouth received higher percentage. The remaining stations show less than $7.0 \%$ distribution. Marine sediments show $1.4 \%$ to $18.0 \%$ of heavy mineral distribution the offshore region received higher percentage than the deeper parts in the marine sediments. Heavy minerals are concentrated as patchy and disseminated forms. The alternate higher and lower percentage of heavy mineral in the marine sediments may be due to the bathymetric conditions. Further due to the erosion activities band longshore current movements, the distribution of heavy mineral is lesser in few stations compared to the other origin. Due to the constant wind action, heavy minerals deposition with varying contents of heavy and light minerals in the form of alternate layers is noticed. Generally, heavy minerals are found to be abundant in erosive beaches, where the winnowing action takes place, leading to the accumulation of heavies. When high wave activity generally expected that the 
accumulation of heavies would be greater. The heavy mineral assemblage of the study region is governed by the distribution of different type of minerals. However, the assemblage is restricted to the dominance of few selective minerals like garnet colourless, garnet pink, zircon, rutile, chlorite, etc.

\subsection{Tuticorin and Ovari, Tamil Nadu, India (M. Suresh Gandhi , E.Vetrimurugan, N.Angusamy, and G.V. Rajamanickam, 2007)}

The heavy mineral assemblage of the study area is given in Table.5a\&b and Figure.7. The heavy mineral assemblage of the study region is governed by the distribution of different type of minerals.

However, the assemblage is restricted to the dominance of few selective minerals like colourless garnet, garnet pink, zircon, rutile, chlorite, etc. From the variation of colour, the garnet is differentiated into two varieties as colourless and pink.

These garnets are identified as pyrope/almandine while the variation in colour is ascribed to certain minor substitutions leading to the formation of pink colour. In Thiruchendur, a complete reduction in zircon is observed with a subsequent increase in chlorites.

In Periyathalai, a clear variation in the abundance of heavy minerals is noticed. In Alanthalai and Manappad beaches, zircon is reduced to a secondary position. An assemblage of colourless garnet, pink garnet and flaky minerals is found to be predominant in this zone. At Ovari, zircon establishes a clear dominance over other minerals. The predominant variety is marked by the abundance of rounded zircons. Only at Ovari, monazite makes an appearance. The dominance garnet helps to demarcate this group into two zones (i) north of Manappad and (ii) south of Manappad. These two zones are characterised by the abundance of garnet and depletion of garnet assemblage respectively. Zircon is found to be less in the north of Manappad coast whereas south of Manappad is dominated by zircons. The highest percentage of zircon is recorded at Ovari beach which is a typical zone of wave convergence. Like other zones, here too the difference in the distribution of various heavy minerals may be assigned to a change in the coastline configuration from NNE-SSW to NE-SW. In Kanyakumari zone, more or less similar assemblages are found in the entire coast. Zircon is represented by the predominant concentration of rounded form over other varieties. Monazite is characteristically distributed in all the beaches. A total reduction in flaky mineral distribution is noticed in all the beaches. Thiruchendur zone is represented by more or less equal distribution of garnet. Periyathalai zone is differentiated from other zones by equal percentage of garnet with topaz, andalusite and sillimanite. Kanyakumari zone is distinguished by slightly higher percentage of zircon, monazite and least amount of chlorite.

\subsection{Tuticorin to Kanyakumari (Saravanan and Chandrasekar, 2005)}

The low concentration of heavy minerals in the samples of Thiruchendur beach and Alanthalai beach is attributable to the oscillation in lowtide zone in the middle layer and hightide zone in the lower sample. In Periyathalai, an oscillation from berm to hightide zone of the present day level is noticed in Periyathalai beach. The variation in heavy mineral concentration in Ovari suggests the condition of lowtide zone.

Kuttankuli and Vijayapathi samples establish similar oscillatory conditions but to a minor level in hightide zone as evidenced from the grain size variation and limited 
variation in distribution of heavies. Kuttapuli samples establish a high percentage of heavy minerals.

The enrichment of lower layer with $48 \%$ of heavies and its reduction to $8 \%$ in middle layer and $2 \%$ in top layer is accounted by oscillations as well as by differing energy conditions in the segregation of heavy minerals. However, Kanyakumari beach samples suggest the withdrawal of sea level to lowtide zone from the existing hightide zone. This is indicated by the presence of very low percentage of heavy minerals in lower and middle layers.

\section{Discussion}

According to Loveson et al (2007) except for Nagoor, all other stations showed erosion of the beaches, with a maximum of $2.5 \mathrm{~m}$, particularly in the Karaikkal area. The study identified two major geomorphologic parts, the first extending from northern Poompuhar to Karaikkal and the second from southern Karaikkal to Nagoor. Changes in the geomorphologic characters observed at these two areas were attributed to the nature of the inner shelf bathymetry. Examination of heavy mineral composition in sediments indicates a dramatic shift in concentration, ranging from 19 to $76 \%$ in the Nagoor area. At Cuddalore to Pondicherry the tsunami affected region is found to have a concentration of coarser fraction in addition to the finer fraction of opaques. The same may be attributed to an added source of Cuddalore sandstone which is in the vicinity of this zone. It is the factor very uncommon to the other zones. Rajamanickam (1968) has projected the preponderance of opaques in the Miocene- Cuddalore sandstones, that too of coarser nature. Such coarser opaques may be added to this zone. Such view has also been supplemented by the distribution of coarser epidote, staurolite and abundance of blue kyanite, which are common in the Cuddalore sandstone. Wave conditions observed during most of the year at stations from Pondicherry to Cuddalore are marked by a strong convergence of wave orthogonals in the SW, NE, and nonmonsoon periods in both $8 \mathrm{~s}$ and $10 \mathrm{~s}$ wave periods.

Under this prevailing high energy environment, flaky minerals such as chlorite, biotite, muscovite, and glaucophane may be moved offshore and reduced in abundance. Denser minerals are abundantly found in these stations due to the continuous winnowing action of the shoaling waves. According to Rajamaickam et al ( 1983 ). When one finds the distribution of heavy minerals by weight percentage from low tide to high tide, the number of poly - modalities prevails uniformly. There is difference in abundance.

In other words, the source show distinct of heavy minerals is expected to remain one and the same. The low tide and high tide show distinct shift in the abundance in six stations studied.

With so much of high energy input, one can easily expect the addition or deletion of certain heavy mineral fraction in this region. When the tsunami is able to shift the deep water forams and outer shelf forams to the beach (Hussain et al., 2006a\&b) it can also add some other heavy minerals present in the route of tsunami waves. It reflects that the heavy minerals deposits are going on for years for only from the shelf sediments. Alternatively the landward migration of the shelf sediments must have been responsible for the type of heavy mineral assemblage in the study area.

Further the frequency distribution between the pre and post tsunami behaves more or less similarly in such a way that the 2 to 2.5 phi grains shows maximum shift in the low tide. It 
may also be surmised that the tsunami energy must have been remained to carry optimum size of 2.5 phi sized heavy minerals in high order of suspension. from the heavy mineral size, one can interpret that the normal energy prevailing in the area may be around 2.5 phi size including the cyclonic stage because the high order of presence of 2.5 phi size grains in the pre tsunami is also seen.

\section{Conclusion}

The analysis of heavy mineral variation has been well established. The eroded areas are associated with fine grained beach sands rich in heavy mineral sands. The difference in the concentration of heavy minerals and the nature of sediments suggest that apart from the river source, some other additional source such as offshore and alongshore must have played a role in making up the compositions of these beach minerals. Further the pattern of enrichment of heavy minerals reflects the nature of longshore grain sorting with reference to the energy conditions prevail in the study area. With all the pre-tsunami beach profiles, it was observed that at least 15 days earlier, there was significant sediment deposition, irrespective of coastline character and behaviour.

After tsunami in many locations, the depositional beaches became erosional and vice versa. The data obtained during pre- and post-tsunami helped assess the selective impacts of the tsunami within a short distance along the shore. Within a coastal distance of $35 \mathrm{~km}$ alternate erosion and deposition of sediments were observed. The various changes observed in sediment landforms and mineralogy indicates the possibility of greater impact through the inner-shelf bathymetry. The concentration of heavy minerals indicates that the outer shelf is the source of origin.

\section{Acknowledgements}

The first author thanks the A.R.Gujar, National Institute of Oceanography, Dona Paula Goa, and Dr.G.Victor Rajamanickam, Director Research, SAIRAM Engineering College, Tambram, Chennai for many suggestions regarding 2004 tsunamigenic sediments and Heavy mineral studies. We also thank Prof. S.P.Mohan. Professor and Head, Department of Geology, University of Madras, for his helpful advice on the manuscript.

\section{References}

Angusamy, N., and Rajamanickam, G.V., (2000) Distribution of Heavy Minerals along the beach from Mandapam to Kanyakumari. Geological Society of India 56: 199-211.

Angusamy.N, Dajkumar Sahayam.J, Suresh Gandhi. M, Victor Rajamanickam. G.V, (2005), Coastal Placer Deposits of Central Tamil Nadu, India. Journal of Marine Georesources and Geotechnology, Volume:23, Page no.1-38.

Anil Cherian (2003) Sedimentological studies in the beaches between Valinokkam and Tuticorin, Tamil Nadu, Unpublished Ph.D.Thesis, Tamil University, Thanajvur, $189 \mathrm{p}$. 
Clague, J.J, Bobrowsky, P.T., and Hutchinson, I. (2000). A review of geological records of large tsunamis at Vancouver Island, British Columbia, and implications for hazard. Quaternary Science Reviews, Vol.19 (9), pp.849-863.

Dominey-Howes, D, Cundy, A., and Croudace, I. (2000). High energy marine flood deposits on Astypalaea Island, Greece: possible evidence for the AD 1956 southern Aegean tsunami. Marine

Geology, Vol.163 (1-4), pp.303-315.

Emery KO and Noakes LC(1968). Economic placer deposits of the continental shelf. In: Technical Bulletin, Economic commission for Asia and Far East, pp 95-111.

Folk R.L (1968) Petrology of Sedimentary rocks Hemphil Austin, Texas 182p.

Hussain, S.M., Gandhi, M.S., Krishnamurthy, R.K., Nagendra, R..(2006a)Micropaleontological investigations of tsunami sediments of Tamil Nadu and Andaman Island.In:26th December 2004 Tsunami, Causes, Effects, Remedial Measures Pre and Post Tsunami Disaster Management: A Geoscientific prospective (Ed-in-Chief: G.V. Rajamanickam) New Academic Publishers, New Delhi, pp. 83-115.

Hussain,S.M.,Krishnamurthy,R.K.,Gandhi,M.S.,Ilayaraja,K.,Ganesan,PandMohan,S.P(2006b) Micropaleontological investigations on tsunamigenic sediments of Andaman Island. Current Science, V.91,Pp.1655-1667.

Iida, Kumizi, Doak C. Cox, and George Pararas-Carayannis, 1967. Preliminary Catalog of Tsunamis Occurring in the Pacific Ocean, HIG-67-10, Hawaii Institute of Geophysics, University of Hawaii, Honolulu, Hawaii, 275 p. Bibliography to the Preliminary Catalog of Tsunamis Occurring in the Pacific Ocean, December 1967, $27 \mathrm{p}$.

Lander, J.F. and Whiteside, L.S., 1997. Caribbean tsunamis: an initial history, http://rmoclis.upr.clu.edu/tsunamis/Lander/J\_Lander.html.

Loverson, V.J., Gujar, A.R., Rajamanickam, G.V., Chandrasekar, N., Soosai Mancikaraja, D., Chandrasekaran, R., Chaturvedi, S.K., Mahesh, R., Josephine, P.J., Vinita Deepa, Sudha, V., and Sunderasan, D., 2007. Post Tsunami Rebuilding of Beaches and the Texture of Sediments, Handbook of Placer deposits, PP.131-146.

Loveson, V. J., Angusamy, N., Gujar, A. R., Chandrasekar, N., Rajamanickam, G. V., 2008, observed inferences from sudden changes in the sedimentological processes during the december 26, 2004 tsunami along the east coast of india. Science of Tsunami Hazards, Vol. 27, No. 4, page43 - 52.

Maramai, A., Graziani, L., and Tinti, S. (2005). Tsunamis in the Aeolian Islands (southern Italy): a review. Marine Geology, Vol.215 (1-2), pp. 11-21.

McMurtry, G.M., Watts, P., Fryer, G.J., Smith, R. and Imamura, F. (2004). Giant landslides, mega-tsunamis, and paleo-sea level in the Hawaiian Islands. Marine Geology, Vol. 203 (3-4), pp.219-233.

Mohan, P.M. and Rajamanickam, G.V.(2001). Indian Beach placers a review in Hand Book of Placer Mineral Deposits. (Editor) G.Victor Rajamanickam, New Academic Publishers New Delhi, PP.23-52.

Monge, J. and Mendoza, J., (1993). Study of the effects of tsunami on the coastal cities of the region of Tarapacá, north Chile. Tectonophysics, Vol. 218 (1-3), pp.237-246. 
Mörner, N. A., (1999). Paleo-tsunamis in Sweden. Physics and Chemistry of the Earth, Part B: Hydrology, Oceans and Atmosphere, Vol. 24 (5), pp. 443-448.

Nakata, I., Kawana, A., Nakatsuji, N., 1993. Perpendicular contact guidance of CNS neuroblasts on artificial microstructures. Development 117: $401 \mathrm{OE} 408$.

Nanayama. F, Shigeno. K, Satake. K, Shimokawa. K, Koitabashi. S, Miyasaka. S and Ishii. M (2000) Sedimentary differences between the 1993 Hokkaido-nansei-oki tsunami and the 1959 Miyakojima typhoon at Taisei, southwestern Hokkaido, northern Japan. Sedimentary Geology, Vol.135 (1-4) pp. 255-264.

NGDC, 2001. Tsunami Database at National Geophysical Data Center, URL: http://www.ngdc.noaa.gov/seg/hazard/tsu.shtml.

Papadopoulos, G. A., and B. J. Chalkis.B. J., (1984). Tsunamis observed in Greece and the surrounding area from antiquity up to the present times. Marine Geology, Vol.56 (1-4), pp.309- 317.

Rajamanickam, G.V., (1968), Heavy mineral studies of cretaceous - tertiary formations of Pondicherry South India, Geo.Soc. of India, Mem, II, p.234-238.

Rajamanickam, G.V. (1983) Geological investigations of offshore heavy mineral placers of Konkan coast, Maharashtra, India. Ph.D.Thesis, Indian school of mines, Dhanbad (Unpublished) $258 \mathrm{p}$.

Rajamanickam, G.V. and Gujar, A.R. (1993) Depositional processes inferred from the log probability distribution. In : Recent Researches in Sedimentology, ed. Jhingran, pp. 154-164.

Rajamanickam and Angusamy (2005) Exploration of placer deposits between Vedaranyam and Pondicherry, Tamil Nadu, India, Technical report submitted to Dept.of Ocean Development, Govt.of India, New Delhi, 220 pp.

Saravanan.S and Chandrasekar.N 2010Distribution and Assemblages of Heavy Mineral Suites, SE India International Journal of Oceans and Oceanography, Volume 4, Number 1, pp. 1-15.

Scheffers, A. and Kelletat, D., (2003). Sedimentologic and geomorphologic tsunami imprints worldwide-a review. Earth-Science Reviews, Vol. 63 (1-2), pp. 83-92.

Shi, S., Dawson, A.G. and Smith, D.E., 1995. Coastal Sedimentation Associated with the December 12th, 1992 Tsunami in Flores, Indonesia, Pure and Applied Geophysics, Vol. 144, No. 3-4, pp. 525-536.

Solai.A., Suresh Gandhi. M., Chandrasekaran. K., and Ram Mohan.V., 2009. Distribution of Heavy Minerals and their Studies in and Around Tamiraparani Estuary and Off Tuticorin Tamil Nadu, India. International Journal of Earth Sciences and Engineering, Volume 2, No.6, PP-527-543.

Suresh Gandhi. M., and Solai. A., Textural and Heavy Mineral Characteristics Surface and Buried Sediments along the Coast between Cuddalore and Pondicherry, Tamil $\mathrm{Nadu}$, India International Journal of Earth sciences and Engineering, Paper Accepted. In Press.

Suresh Gandhi. M., Vetrimurugan. E., Angusamy. N., Victor Rajamanickam. G., 2007. The effect of Tsunami on the placer mineral distribution in the beaches between Tuticorin and Ovari, Tamil Nadu, In Journal of Earth Sciences, Vol. 1, No. 3, pp. 2334, ,ICFAI, Hyderabad. 
Tappin, D. R., Watts, P., McMurtry, G. M, Lafoy, Y. and Matsumoto, T. (2001). The Sissano, Papua New Guinea tsunami of July 1998 - offshore evidence on the source mechanism. Marine Geology, Vol.175 (1-4), pp.1-23. 


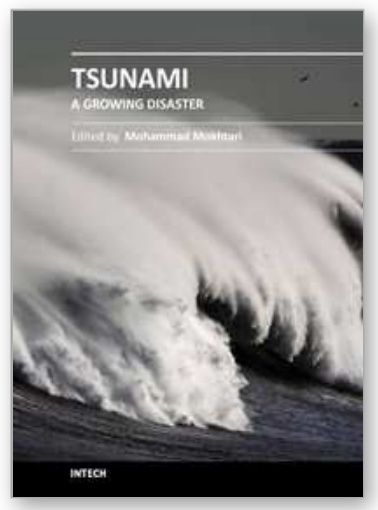

\author{
Tsunami - A Growing Disaster \\ Edited by Prof. Mohammad Mokhtari
}

ISBN 978-953-307-431-3

Hard cover, 232 pages

Publisher InTech

Published online 16, December, 2011

Published in print edition December, 2011

The objective of this multi-disciplinary book is to provide a collection of expert writing on different aspects of pre- and post- tsunami developments and management techniques. It is intended to be distributed within the scientific community and among the decision makers for tsunami risk reduction. The presented chapters have been thoroughly reviewed and accepted for publication. It presents advanced methods for tsunami measurement using Ocean-bottom pressure sensor, kinematic GPS buoy, satellite altimetry, Paleotsunami, lonospheric sounding, early warning system, and scenario based numerical modeling. It continues to present case studies from the Northern Caribbean, Makran region and Tamil Nadu coast in India. Furthermore, classifying tsunamis into local, regional and global, their possible impact on the region and its immediate vicinity is highlighted. It also includes the effects of tsunami hazard on the coastal environment and infrastructure (structures, lifelines, water resources, bridges, dykes, etc.); and finally the need for emergency medical response preparedness and the prevention of psychological consequences of the affected survivors has been discussed.

\title{
How to reference
}

In order to correctly reference this scholarly work, feel free to copy and paste the following:

M. Suresh Gandhi, A. Solai, Sivaraj Kaveri, Kasilingam Kanan, Venkatesan Dhamodharan, Kuppusamy Baskar and Victor Rajamanickam (2011). Post Tsunami Heavy Mineral Distribution Between Cuddalore to Kanyakumari Along the Tamil Nadu Coast, India - A Review, Tsunami - A Growing Disaster, Prof. Mohammad Mokhtari (Ed.), ISBN: 978-953-307-431-3, InTech, Available from: http://www.intechopen.com/books/tsunamia-growing-disaster/post-tsunami-heavy-mineral-distribution-between-cuddalore-to-kanyakumari-along-thetamil-nadu-coast-

\section{INTECH}

open science | open minds

\author{
InTech Europe \\ University Campus STeP Ri \\ Slavka Krautzeka 83/A \\ 51000 Rijeka, Croatia \\ Phone: +385 (51) 770447 \\ Fax: +385 (51) 686166 \\ www.intechopen.com
}

\author{
InTech China \\ Unit 405, Office Block, Hotel Equatorial Shanghai \\ No.65, Yan An Road (West), Shanghai, 200040, China \\ 中国上海市延安西路65号上海国际贵都大饭店办公楼 405 单元 \\ Phone: +86-21-62489820 \\ Fax: +86-21-62489821
}


(C) 2011 The Author(s). Licensee IntechOpen. This is an open access article distributed under the terms of the Creative Commons Attribution 3.0 License, which permits unrestricted use, distribution, and reproduction in any medium, provided the original work is properly cited. 